\title{
Kebutuhan Informasi di Bidang Politik Dewan Perwakilan Cabang Persatuan Tunanetra Indonesia Malang pada Pemilu Serentak 2019
}

\author{
Amalia Nurma Dewi ${ }^{*}$; Dwi Novita Ernaningsih ${ }^{1}$ \\ ${ }^{1}$ Program Studi Ilmu Perpustakaan Universitas Negeri Malang \\ *Korespondensi: amalia.nurma.fs@um.ac.id
}

\begin{abstract}
In the Indonesian general election of 2014 , the blind community signed a petition to not to participate in presidential election because even though they had been given the right to information, they did not receive relevant information. In 2019, Indonesia held the first simultaneous election, and the government made various efforts to improve the information accessibility, however, the information provided by the government was solely based on what the government thought the blind community needed, rather, than what the community actually did need. With affinity, the focus of this research is to analyze information needs of the blind community with the aim to increase the information literacy of the Pertuni Malang for the next election. The method which is used in this article is qualitative involving a case study approach. Information needs can be understood from four dimensions, namely function, form, agents and mechanisms. The finding for function dimension shows that on the 2019 Concurrent Elections the need for information of the Pertuni community arose because they were aware of their role as citizens and members of Pertuni. Form dimension shows the information needs related to the election procedures, braille voting templates, advocacy, and the background of legislative candidates. The agent dimension shows that the producer of information is the KPU; the information seeker is the Pertuni; and the processor is the MCW and Pertuni administrators. The mechanism shows that they look for information through television and communication
\end{abstract}

Keywords: Information needs; simultanious election; blind community

\begin{abstract}
Abstrak
Pada pemilihan umum 2014 komunitas tunanetra menandatangani petisi untuk abstain karena mereka tidak mendapatkan hak informasi. Tahun 2019 Indonesia mengadakan Pemilu Serentak untuk pertama kalinya. Pemerintah melakukan berbagai usaha untuk meningkatkan aksesbilitas informasi tunanetra dalam pemilu tersebut, tetapi informasi yang diberikan hanya informasi yang menurut pemerintah diperlukan oleh tunanetra. Melihat hal tersebut fokus penelitian ini ada pada analisis kebutuhan informasi dengan tujuan untuk meningkatkan literasi informasi komunitas Pertuni pada pemilu selanjutnya. Metode yang digunakan adalah kualitatif dengan pendekatan studi kasus. Kebutuhan informasi dilihat dari empat dimensi yaitu function, form, agents dan mechanisms. Pada dimensi function diketahui kebutuhan informasi tentang Pemilu Serentak 2019 muncul karena mereka menyadari peran mereka sebagai warga negara dan sebagai anggota komunitas Pertuni. Pada dimensi function ditemukan ada empat kebutuhan informasi utama yaitu tata cara pemilu, template suara braille, advokasi, dan latar belakang calon legislatif. Dimensi agents berkaitan dengan pihak mana yang berperan sebagai produsen informasi, pencari, dan prosesor. Produsen informasi adalah KPU, pencari informasi adalah Komunitas Pertuni Malang, dan prosesor adalah MCW dan pengurus Pertuni. Dimensi mechanisms berkaitan dengan bagaimana kebutuhan informasi tersebut dipenuhi, yaitu melalui televisi dan melalui komunikasi dengan pengurus pertuni.
\end{abstract}

Kata kunci: Perilaku informasi; pemilu serentak; pertuni

\section{PENDAHULUAN}

Sandra Braman dalam bukunya, Change of State menyatakan bahwa sejak tahun 1960 terjadi pergeseran dari bureucratic state menjadi Information State. Pergeseran tersebut menyebabkan meningkatnya peran informasi dalam bidang politik. Informasi dilihat sebagai kekuatan. Kekuatan yang mampu memberdayakan warga negara untuk mengontrol dan menyeimbangkan jalannya pemerintahan demi terwujudnya suatu sistem pemerintahan yang baik (good governance), tetapi pada praktiknya tidak semua informasi mampu membantu terwujudnya good governance (Braman, 2007).

Syarat agar informasi bisa membantu mewujudkan good governance adalah informasi tersebut harus sesuai dengan kebutuhan politik warga negara, sehingga mereka tahu hak dan kewajibannya, dan tahu bagaimana ikut berperan dalam partisipasi politik demi mewujudkan sistem 
pemerintahan yang kuat (Andriadi, 2016). Salah satu informasi politik yang mempunyai peran penting dalam sistem pemerintahan adalah informasi tentang pemilihan umum. Menurut Heryanto, pemilihan umum merupakan salah satu tonggak dari negara demokrasi, dimana setiap warga negara, tanpa terkecuali mempunyai hak yang sama untuk memberikan aspirasi politiknya demi masa depan bangsa (Heryanto, 2019).

Aspirasi politik warga negara bisa diekspresikan secara maksimal saat mereka mendapatkan informasi yang memadai. Selama ini ada kecenderungan bahwa aspirasi politik masyarakat dalam pemilu belum didasari oleh informasi politik yang kuat, kebanyakan dari mereka hanya mengikuti arus pendapat yang populer, sehingga orientasi politik mereka mudah dimanipulasi (Alexander, 2009). Dampak kurangnya informasi tentang pemilu yang lebih signifikan dirasakan oleh kelompok masyarakat dengan keterbatasan indra penglihatan yaitu tunanetra

Indonesia sebagai negara yang memiliki populasi tunanetra terbesar kedua di dunia (UNDP, 2017) telah berusaha melakukan perlindungan terhadap hak-hak kelompok difabilitas melalui Undang-Undang hak Asasi Manusia nomor 39 tahun 1999 pada pasal 41 yang menyatakan bahwa "para penyandang cacat berhak memperoleh kemudahan dan perlakuan khusus"(UU nomor 39 tahun 1999). Kemudahan dan perlakuan khusus pada pasal di atas mengacu pada toleransi terhadap berbagai jenis keterbatasan yang dimiliki oleh kaum difabilitas harus difasilitasi agar mereka bisa berpartisipasi seperti masyarakat lain. Toleransi dan fasilitas tersebut harus mencakup segala aspek dalam kehidupan difabilitas termasuk dalam kaitannya dengan informasi.

Tidak dapat dipungkiri, walaupun perundang-undangan yang mengatur tentang perlindungan terhadap hak informasi kelompok masyarakat difabilitas telah disahkan, tetapi pada prakteknya selalu ada kesenjangan saat undang-undang tersebut dijalankan. Salah satu kesenjangan yang berdampak pada pelanggaran hak informasi kemudian berpengaruh pada hak politik warganegara terjadi pada pemilihan umum presiden tahun 2014, dimana enam komunitas yang mewakili tunanetra di Indonesia mengadakan konfrensi di gedung Indonesia menggugat.

Mereka menyatakan bahwa tunanetra membutuhkan template huruf braille agar mereka bisa "membaca informasi" tentang kandidat capres dan cawapres secara mandiri. Tuntutan keenam komunitas tunanetra tidak direspon selama beberapa waktu, sehingga menyebabkan mereka menandatangani petisi untuk tidak berpartisipasi dalam pemilu 2014 (liputan 6, 2014). Kasus pada pemilihan umum 2014 tersebut merupakan contoh pentingnya pemahaman akan kebutuhan informasi masyarakat tunanetra dalam pemilu.

Berdasarkan apa yang terjadi pada pemilihan umum 2014, peneliti ingin menganalisis kebutuhan informasi dalam pemilihan umum serentak tahun 2019 dari sebuah komunitas tunanetra yaitu Dewan Perwakilan Cabang Persatuan Tunanetra Indonesia Malang (DPC Pertuni Malang). DPC Pertuni Malang merupakan cabang dari komunitas pertuni yang ada di Malang, kegiatan dari komunitas DPC Pertuni Malang ditujukan untuk meningkatkan kualitas literasi informasi, meningkatkan kekuatan ekonomi, pendidikan, dan juga politik dari anggotanya demi memajukan kualitas hidup tunanetra yang ada di Malang (Suryadi, 2019).

Kaitannya dengan Pemilu, pihak DPC Pertuni Malang dengan aktif berusaha untuk melakukan kolaborasi dengan berbagai pihak untuk dapat memenuhi kebutuhan informasi mereka. Tetapi, selama ini belum pernah dilakukan analisis terhadap kebutuhan informasi anggota komunitas terkait pemilihan umum. Kerjasama yang dilakukan berupa sosialisasi yang diberikan kepada pihak pertuni dilakukan tanpa didahului oleh analisis kebutuhan informasi, sehingga materi yang diberikan hanya berkaitan dengan apa yang dianggap oleh pihak kolaborator penting bagi anggota pertuni, tetapi menurut anggota masih belum sesuai. Melihat fakta tersebut maka perlu dilakukan analisis kebutuhan informasi berkaitan dengan pemilu pada DPC Komunitas Pertuni Malang demi meningkatkan pengetahuan akan informasi politik dan pada akhirnya bisa memaksimalkan partisipasi komunitas tersebut dalam pemilu. 
Penelitian terdahulu tentang kebutuhan informasi tunanetra dilakukan oleh Retty Dina Lestari dengan judul Kebutuhan Informasi Penyandang Cacat Tunanetra pada SMPLB YPAB Surabaya dengan menggunakan teori kebutuhan informasi dari TD Willson (Lestari, 2017). Hasil dari penelitian tersebut menunjukkan bahwa kebutuhan informasi tunanetra khususnya pada siswa sekolah menengah pertama berupa kebutuhan pendidikan dan hobi serta kebutuhan penunjang untuk kehidupan sehari-hari. Sumber informasi yang digunakan adalah televisi, radio, buku bicara, internet maupun dengan cara mengikuti program atau pelatihan yang diadakan di sekolah.

Kelemahan dari penelitian terdahulu adalah sasaran penelitian ditujukan pada siswa tunanetra yang ada di SLB menyebabkan kebutuhan informasi mudah diprediksi dan kurang beragam. Lingkungan sosial berupa sekolah yang lebih terkondisikan menyebabkan permasalahan yang dihadapi oleh tunanetra dalam penelitian tersebut kompleksitasnya belum bisa mewakili kebutuhan tunanetra yang mereka benar-benar telah terjun ke masyarakat. Sasaran penelitian dalam artikel ini adalah komunitas tunanetra yang memiliki anggota dengan latar belakang berbeda dimana mereka merupakan individu dewasa yang telah terjun ke masyarakat, sehingga permasalahan terkait kebutuhan informasi yang digambarkan dalam artikel ini akan lebih bisa mendekati kondisi nyata tunanetra yang ada di masyarakat.

Selain itu, dalam artikel ini penulis menggunakan Model Kebutuhan Informasi Sosial dari Moore yang didesain dan dikembangkan berdasarkan hasil penelitian terhadap kelompok masyarakat tunanetra, sehingga teori yang digunakan lebih mampu untuk memberikan analisis mendalam dalam mengkaji kebutuhan informasi Komunitas Pertuni Malang dalam Pemilu Serentak 2019. Moore membagi Model Kebutuhan Informasi Sosial menjadi enam dimensi, yaitu function, form, clusters, agents, users, dan mechanisms. Dimensi pertama yaitu function, konteks function dalam model perilaku informasi sosial berkaitan dengan alasan mengapa tunanetra membutuhkan informasi tersebut. Moore membagi function menjadi dua, yaitu tunanetra membutuhkan informasi untuk memenuhi perannya sebagai warga negara dan sebagai konsumer.

Sebagai warga negara tunanetra mempunyai kewajiban untuk membuat pilihan yang demokratis, untuk itu mereka perlu landasan informasi yang kuat agar bisa membuat pilihan yang bijak bagi kepentingan bersama dan kepentingan pribadinya. Dimensi function juga berkaitan dengan peran tunanetra sebagai konsumen yang bukan hanya terbatas pada kemampuan membandingkan produk $\mathrm{X}$ lebih baik dari produk $\mathrm{Y}$, Moore menjelaskan bahwa informasi digunakan untuk membantu tunanetra dalam memilih berbagai produk baik dari pemerintah ataupun swasta, dalam bentuk layanan sosial dan lainnya yang yang sesuai untuk meningkatkan kualitas hidup mereka.

Dimensi kedua yaitu form yang berkaitan dengan informasi apa saja yang dibutuhkan oleh tunanetra. Moore membagi dimensi form menjadi analisis lingkungan, maksudnya adalah kebutuhan informasi yang ada tetapi tidak disadari oleh tunanetra dan mereka memenuhi kebutuhan informasi tersebut dengan cara yang "tidak sengaja", dari apa yang mereka dengar. Setelah analisis lingkungan dimensi form juga mencakup kebutuhan informasi yang digunakan untuk menjawab pertanyaan yang berkaitan dengan menjawab kebutuhan praktikal sehari-hari, seperti kapan mereka bisa menghubungi dokter, pukul berapa kreta akan berangkat, dsb. Di tingkatan selanjutnya ada advokasi. Advokasi berarti bahwa informasi yang dibutuhkan oleh tunanetra berkaitan dengan bagaimana cara mereka memperoleh hak-haknya sebagai warga negara.

Dimensi ketiga yaitu clusters yang berarti mengelompokan kebutuhan informasi yang ada pada dimensi form berdasarkan tingkat kebutuhan dari Mashlow atau berdasarkan life events. Tujuan dari pengelompokkan ini adalah untuk mendapatkan gambaran yang lebih komperhensif tentang faktor-faktor eksternal yang mempengaruhi kesamaan kebutuhan informasi antara individu yang satu dengan individu yang lain. 
Dimensi keempat adalah agents yang berarti pihak yang berperan dalam pemenuhan kebutuhan informasi. Dibagi menjadi tiga yaitu produsen, pencari, dan processor. Produsen adalah pihak yang memproduksi informasi, pengguna adalah pihak yang memanfaatkan informasi, dan processor adalah pihak yang menyedikan informasi sesuai dengan kebutuhan pengguna melalui proses repackaging dan filterisasi informasi.

Dimensi kelima adalah pengguna, dalam dimensi ini Moore berargumen bahwa pengguna yang berkelompok akan memiliki kecenderungan kebutuhan informasi yang sama, tetapi kekuatan kelompok tersebut tidak sepenuhnya mempengaruhi keseluruhan kebutuhan informasi seseorang. Kelompok akan mempengaruhi kebutuhan individu dalam level tertentu, semakin kuat identitas dan rasa keterikatan terhadap kelompok maka akan muncul kecenderungan yang semakin kuat pada kesamaan kebutuhan informasi kelompok pengguna tersebut. Dimensi keenam adalah mechanism, didefinisikan sebagai cara seseorang dalam mendapatkan informasi seperti merekam, menyimpan menduplikasi, membuat ulang, mengkomunikasikan, dan mengemas ulang informasi.

Pada artikel ini peneliti mengambil empat dimensi yaitu dimensi function, form, agents, dan mechanisms. Alasan pemilihan empat dimensi karena pada teori Kebutuhan Informasi Sosial Moore pada dimensi clusters memiliki kesamaan ide dengan dimensi form yaitu tentang jenis kebutuhan informasi yang dimunculkan. Dimensi users memiliki kesamaan dengan dimensi agents pada bagian seeker atau pencari, dengan pertimbangan tersebut maka penelitian ini mengambil empat dimensi dari Model Kebutuhan Informasi Sosial. Diawali dengan mengetahui alasan munculnya kebutuhan informasi pemilu serentak 2019 (function), cakupan kebutuhan informasi tentang pemilu (forms), siapa saja yang berperan dalam memproduksi, mencari, dan memproses kebutuhan informasi tentang pemilu tersebut (agents) dan cara pemenuhannya (mechanisms).

\section{METODE PENELITIAN}

Artikel Kebutuhan Informasi Bidang Politik untuk Komunitas DPC Pertuni di Kota Malang ini menggunakan pendekatan kualitatif dengan metode studi kasus. Pendekatan kualitatif dipilih karena tujuan penelitian ini untuk mendapatkan pemahaman menyeluruh dan mendalam terhadap kebutuhan informasi dari suatu komunitas yaitu DPC Pertuni Malang terkait pemilu serentak tahun 2019 pada setting alamiahnya yang dianalisis menggunakan model kebutuhan informasi sosial yang dilihat dari empat dimensi yaitu a) function, alasan komunitas membutuhkan informasi tentang pemilu, b) form, informasi apa tentang pemilu yang mereka butuhka, c) agents berkaitan dengan pihak yang berperan dalam penyebaran kebutuhan informasi, dan d) mechanisms, cara pemenuhan kebutuhan informasi (Moore, 2002).

Data dari penelitian ini adalah perilaku informasi Komunitas Dewan Perwakilan Cabang Pertuni Malang dalam kaitannya dengan Pemilu Serentak tahun 2019. Sumber data dari penelitian ini adalah seluruh anggotan Dewan Perwakilan Cabang Pertuni Malang, Perwakilan Malang Corruption Watch, dan Perwakilan Komisi Pemilihan Umum Malang, yang dikumpulkan melalui observasi, wawancara, dan studi dokumen.

\section{HASIL DAN PEMBAHASAN}

\section{Dimensi I- Function}

Berdasarkan teori Moore, dimensi function mencakup alasan seseorang membutuhkan informasi yang berkaitan dengan perannya sebagai warga negara dan sebagai konsumen. Pada anggota DPC Komunitas Pertuni kebutuhan informasi yang berkaitan dengan pemilihan umum serentak, beberapa anggota inti dan ketua komunitas menjawab bahwa alasan mereka membutuhkan informasi karena mereka menyadari bahwa hak mereka sebagai warga negara adalah menyalurkan aspirasi politknya melalui pemilihan umum 
"karena ya kita walaupun ngga bisa lihat apa-apa tapi hak kita kan tetap sama dengan warga negara lain" (Ari)

"biar kita itu bisa ikut ngeramein pemilu serentak, selama ini banyak dari kita yang tidak berpartisipasi, dikiranya kita itu nggak peduli, padahal kita peduli loh mba, tapi kita kurang informasi dan sudah berusaha mengajukan tapi responnya lamban kalau ingin ikut tapi tidak tahu apa-apa, rasanya itu gimana soalnya ada beberapa kasus kita itu dibohongi (Sunu)

"kita butuh sekali informasi tentang pemilu $m b a$, orang netra itu sebenarnya lebih butuh bantuan informasi dibandingkan yang lainnya, karena kita ngga bisa lihat sehingga informasi yang kita butuhkan itu spesial dan susah dapetnya (Mas)

Dari kutipan wawancara di atas, anggota komunitas tidak sekedar menyadari posisi mereka sebagai warga negara, tetapi lebih dari itu mereka menyadari karena keterbatasan indra penglihatan yang dimiliki menyebabkan mereka mudah dimanipulasi dan dirugikan secara politis. Beberapa anggota mendapat pengalaman buruk pada pemilihan umum sebelumnya, dimana hak pilih mereka disalahgunakan, hal tersebut menyebabkan komunitas pertuni bersikap lebih waspada terhadap orang-orang sekitar dan juga meningkatkan motivasi mereka dalam memenuhi kebutuhan informasi.

Kejadian penyalahgunaan hak pilih tersebut memotivasi ketua komunitas bersikap antisipatif dengan cara lebih proaktif dalam memenuhi kebutuhan informasi tentang pemilu dari berbagai badan pemerintahan ataupun NGO untuk anggota komunitas. Pada era dimana informasi di lihat sebagai kekuatan (Braman, 2007), maka untuk memperkuat posisi mereka sebagai warga negara, komunitas pertuni menyadari bahwa pemenuhan kebutuhan informasi adalah suatu keharusan.

Ketua komunitas menyadari bahwa selama ini pemerintah maupun masyarakat kurang memperhatikan kebutuhan informasi pemilu dari kelompok masyarakat tunanetra. Sikap pasif yang ditunjukkan oleh komunitas pertuni sebelumnya dalam menunggu pihak lain memberikan akses informasi tentang pemilu ternyata membuat mereka kekurangan informasi, sehingga untuk menghadapi pemilihan umum serentak tahun 2019 beberapa anggota dan ketua komunitas saling membantu untuk mendapatkan informasi dengan cara sharing dengan komunitas pertuni di daerah lain tentang informasi pemilu apa saja yang mereka sudah dapatkan dan bagaimana cara mendapatkannya, menghubungi KPU untuk mendapatkan sosialisasi khusus tentang pemilu untuk tunanetra, dan Malang Corruption Watch untuk mendapatkan pelatihan kesadaran berpolitik.

Selain dilatarbelakangi oleh peran anggota komunitas sebagai warga negara, ternyata alasan lain yang memunculkan kebutuhan informasi tentang pemilu serentak adalah ikatan antar anggota komunitas yang kuat. Ikatan tersebut mempengaruhi kebutuhan informasi anggotanya, sehingga kebutuhan informasi tentang pemilu tidak murni muncul dari kesadaran individu tiap anggota komunitas tetapi muncul juga karena rangsangan dari komunitas. Ahmadpour menyatakan bahwa kebutuhan informasi bukan suatu proses tertutup antara individu dan informasi, tetapi ia adalah suatu proses terbuka yang dipengaruhi oleh berbagai macam faktor termasuk lingkungan sosial (komunitas) disekitar (Kamran, 2015)

Kesadaran sebagai warganegara ditunjukkan oleh ketua komunitas dan anggota inti/pengurus komunitas, sementara untuk anggota lain kebutuhan informasi tersebut muncul karena keinginan mereka untuk menjadi bagian dari komunitas, karena ketua dan anggota kunci komunitas memiliki posisi yang kuat, dimana mereka bisa mempengaruhi pemikiran dan sikap dari anggota, sehingga saat ketua dan anggota inti mempunyai ketertarikan akan isu pemilihan umum serentak, maka anggota lain pun akan mengikuti. Berikut ini kutipan wawancara yang menunjukkan hal tersebut 
"Pengen taunya si karena teman-teman sering ngobrolin tentang pemilu itu, kalau ga nyambung rasanya ngga enak" (Ari)

"Masa anak-anak tahu saya tidak, ngga gaul dong" (Dian)

"kalo pas bola ya kita ngomongin bola, kalo ramenya pemilu ya saya ikut aja" (Fani)

Kutipan di atas menunjukkan, keinginan diakui dan menjadi bagian dari suatu kelompok mendorong anggota untuk memunculkan kebutuhan informasi yang sama, hal tersebut sejalan dengan apa yang dinyatakan oleh Wilson yang menyatakan bahwa kebutuhan akan informasi bukanlah suatu proses tertutup antara seorang individu dan informasi, tetapi lebih dari itu kebutuhan informasi dipengaruhi oleh faktor eksternal seperti interaksi individu dengan masyarakat sekitar (Wilson, 2016).

Berdasarkan uraian di atas dapat disimpulkan bahwa untuk dimensi function selain dipengaruhi oleh peran seseorang sebagai warganegara juga dipengaruhi oleh peran seseorang sebagai anggota komunitas.

\section{Dimensi II-Form}

Dimensi Form berkaitan dengan informasi apa yang diperlukan oleh seseorang. Pada penelitian ini dimensi form digunakan untuk menganalisis informasi apa saja yang menjadi prioritas kebutuhan Komunitas DPC Pertuni Malang dalam Pemilu Serentak 2019. Berikut adalah hasilnya:

Tabel 1

Kebutuhan Informasi utama tentang Pemilu pada DPC Pertuni Malang

\begin{tabular}{clc}
\hline No. & Kebutuhan Informasi & Presentase (\%) \\
\hline 1. & Tata cara pemilihan umum untuk tunanetra & 35 \\
2. & Template surat suara braille & 35 \\
3. & Cara melakukan advokasi dalam menuntut hak dalam pemilu & 20 \\
4. & Latar belakang calon legislatif & 10 \\
\hline
\end{tabular}

Berdasarkan tabel tersebut bisa dilihat bahwa sebanyak 35\% anggota komunitas menyatakan bahwa kebutuhan informasi utama mereka berkaitan dengan tata cara pemilihan umum untuk tunanetra. Kebutuhan tersebut muncul dilatarbelakangi oleh pengalaman beberapa anggota pada pemilihan umum sebelumnya, dimana petugas tempat pemungutan suara (TPS) kurang tanggap dalam membantu tunanetra memberikan hak pilihnya.

Selain itu masih sering ditemukan hal-hal kecil yang mengganggu aksesbilitas menuju TPS, seperti penataan tempat duduk di TPS yang terlalu berdekatan sehingga membuat tunanetra tersandung saat menuju bilik suara, bilik suara yang letaknya terlalu tinggi, dan kebingungan pendamping dalam berinteraksi serta memberikan bantuan tunanetra pada saat mencoblos kertas suara. Anggota Pertuni berharap bahwa mereka, petugas TPS, dan juga pendamping mendapatkan informasi tentang bagaimana tata cara dalam melakukan pencoblosan dan dalam membantu tunanetra menyalurkan hak pilih dalam pemilu, serta informasi tentang bagaimana mereka menuntut haknya saat pihak lain (petugas dan pendamping) tidak mematuhi tata cara yang telah ditentukan.

Informasi yang berkaitan dengan tatacara pemilihan umum ternyata mempunyai dampak signifikan terhadap motivasi anggota dalam melakukan pemilihan. Anggota menyatakan bahwa saat mereka tidak diberikan informasi tentang tata cara pemilihan mereka enggan untuk memberikan hak pilihnya karena memunculkan anxiety. Fakta tersebut sesuai dengan pernyataan Wurman bahwa terlalu sedikit ataupun terlalu banyak informasi memunculkan apa yang disebut Wurman sebagai information anxiety (Wurman, 2000). Mereka merasa bahwa kebutuhan khusus yang mereka miliki hanya merepotkan orang-orang disekitar dan membuat mereka merasa tidak nyaman. Lain halnya jika da informasi tentang tata cara pemilihan umum tersebut diinformasikan kepada seluruh pihak terkait, anggota merasa mereka akan lebih "aman" saat meminta pihak lain 
mengikuti tata cara dan prosedur yang ada. Berikut ini adalah wawancara yang menunjukkan hal tersebut:

"kadang ewuh mba kalau mau meminta tolong ke petugas TPS nya, kadang mereka juga tidak mau kita ribetin"'(AA)

"aku sering mba nabrak-nabrak bangku terus orang-orang yang di TPS itu ketawa rasanya itu gimana ya... siapa sih yang mau jadi orang netra" (BB)

"kalau sudah di informasikan, di tata tata cara pemilihannya bagaimana kan sama-sama enak mba, jadi kita itu tidak sungkan untuk meminta petugas atau pendamping jika mereka tidak mengikuti tata cara" (SN)

Dari tabel dan kutipan wawancara kita bisa menyimpulkan bahwa informasi tentang tata cara dalam pemilihan umum dibutuhkan oleh anggota pertuni, tanpa informasi tersebut mereka merasa insecure dalam memberikan hak pilih mereka saat pemilihan umum. Informasi tentang tata cara diharapkan tidak hanya diketahui oleh pihak pemilih saja tetapi juga oleh petugas TPS dan pendamping dengan tujuan agar semua pihak yang terlibat bisa mengetahui hak dan kewajiban mereka dalam proses pemilihan umum sehingga proses pemilihan umum bisa dilaksanakan secara efektif dan efisien.

$35 \%$ anggota pertuni juga menyatakan bahwa kebutuhan informasi mereka dalam pemilihan umum berkaitan dengan template surat suara braille. Surat suara dalam huruf braille ini memungkinkan tunanetra untuk bisa menjadi pemilih mandiri, mereka tidak memerlukan pendamping dalam memberikan hak pilih karena informasi tentang nomor urut dan calon legislatif bisa mereka "baca sendiri", sehingga prinsip pemilu yaitu luber jurdil (langsung, umum, bebas, rahasia, jujur, dan adil) bisa diterapkan dengan baik.

Pada kenyataannya, dalam proses pemilu prinsip tersebut belum dipegang teguh. Pada pemilu tahun 2014 dan 2019 yang lalu, pihak komunitas merasa kecewa karena mereka tidak mendapatkan format braille padahal pada masa sebelum pemilu pihak KPU menginformasikan bahwa mereka akan mendapatkan format tersebut. Tidak disediakannya format braille menyalahi prinsip utama pemilu yaitu jujur, rahasia, dan adil (Kementrian Komunikasi \& Informatika, 2019).

Pelanggaran terhadap tiga hal tersebut terjadi karena dalam proses pencoblosan anggota tunanetra membutuhkan pendamping. Pendamping adalah orang yang membantu tunanetra memberikan hak suaranya pada kertas suara karena tidak adanya kertas suara huruf braille, hal tersebut tentunya melanggar prinsip kerahasiaan karena ada pihak lain yang mengetahui siapa yang dipilih oleh anggota komunitas.

Kedua prinsip jujur, beberapa kali anggota komunitas menyatakan mereka dicurangi oleh pendamping mereka, contoh kasus yang baru saja terjadi, salah satu anggota datang tanpa keluarga, sehingga pendamping yang diambil bukanlah anggota keluarga seperti biasanya, sebelum anggota pertuni tersebut memilih calon yang akan dicoblos dia mendengar surat suara sudah dicoblos oleh pihak pendamping dan saat dikonfirmasi pihak pendamping hanya berkata "sudah nurut saja" (Adi) hal tersebut menimbulkan kecurigaan tetapi anggota pertuni yang mengalami kejadian tersebut hanya bisa pasrah saja karena kekurangan indra penglihatan mereka.

"pasrah yo mba wong yo aku ga iso ndelok"(Ari)

Dari kejadian di atas tentu saja prinsip jujur sudah dilanggar. Prinsip keadilan juga dilanggar karena tidak adanya kesetaraan akses informasi bagi anggota komunitas.

Jadi informasi akan surat suara dalam huruf braille diperlukan oleh anggota komunitas karena tanpa surat suara tersebut hak mereka sebagai warga negara sering kali dirampas yang secara otomatis juga melanggar prinsip luber jurdil dari pemilu.

Sebanyak 20\% anggota menyatakan bahwa kebutuhan informasi utama mereka dalam pemilu adalah cara melakukan advokasi dalam menuntut hak yang seharusnya mereka dapatkan. Menurut para anggota yang memberikan jawaban tersebut selama ini mereka sebenarnya sudah tahu hak dan 
kewajiban dalam pemilu, begitu pun pihak penyelenggara, tetapi pengetahuan tersebut tidak serta merta membuat mereka bisa melaksanakan kewajiban dan mendapatkan haknya. Mereka berpendapat bahwa pemerintah seharusnya juga melakukan sosialisasi bagaimana cara agar komunitas mendapatkan advokasi terkait hak yang tidak mereka dapatkan.

Pernyataan di atas sesuai dengan pernyataan Moore yang menyatakan bahwa informasi yang diberikan kepada tunanetra sebagai warga negara kebanyakan terkait dengan hak dan kewajibannya, tetapi informasi tentang bagaimana mereka harus menuntut haknya saat hak tersebut tidak dipenuhi masih minim sehingga pelanggaran terhadap hak-hak tunanetra sebagai warga negara terus berlangsung (Moore, 2002).

Dari uraian di atas dapat disimpulkan bahwa tanpa informasi tentang advokasi terhadap hak anggota komunitas yang tidak mereka dapatkan dalam pemilu menyebabkan pelanggaranpelanggaran terhadap hak tunanetra terus berlanjut tanpa adanya upaya maksimal untuk mendapatkan/menuntut haknya, pengulangan terhadap pelanggaran hak dalam pemilu membuat anggota komunitas menganggap pelanggaran tersebut bukan lagi sebagai pelanggaran tetapi sebagai hal yang biasa dan wajar terjadi.

Sebanyak 10\% anggota menyatakan bahwa kebutuhan informasi utama mereka berkaitan dengan atar belakang calon legislatif dalam pemilu 2019. Kebutuhan tersebut muncul karena kekhawatiran para anggota terhadap beberapa calon legislatif daerah yang datang ke komunitas mereka selama masa kampanye. Kedatangan para calon legislatif tersebut selain untuk meminta dukungan anggota komunitas terkadang juga diselingi informasi yang menjelekkan lawan politiknya, anggota komunitas merasa khawatir jika anggota lain terpovokasi oleh informasi tersebut.

"pertama si biasanya minta doa mba biar terpilih, tapi setelah itu kadang diselingi omongan kayak "milihnya saya aja yang peduli sama teman-teman disini, yang lain mana peduli", kasarannya seperti itu" mba" (Suni)

"kalau datangnya baik-baik ya kami terima, hanya kadang itu diselingi berita yang agak macem-macem takutnya ada teman lain yang percaya, yang datang mungkin mikirnya karena kita buta jadi gampang dibohongi" (Ari)

Dari kutipan dan penjelasan di atas kita bisa menyimpulkan bahwa komunitas tunanetra sudah mampu bersikap waspada dan kritis terhadap berita tentang calon legislatif, mereka tidak sepenuhnya percaya jika ada calon legislatif yang datang ke mereka dan menjelek-jelekan calon legislatif lain. Anggota komunitas merasa khawatir jika mereka didisorientasikan secara politik.

Kesimpulan dari poin kedua yaitu kebutuhan informasi menunjukkan bahwa pengalaman selama pemilu mempengaruhi jenis kebutuhan informasi anggota komunitas DPC Pertuni. Pengalaman yang memiliki pengaruh signifikan terhadap kebutuhan informasi ternyata adalah pengalaman yang berkaitan dengan tidak dipenuhinya hak pertuni sebagai warga negara, yang kemudian menimbulkan anxiety. Pengalaman-pengalaman tersebut menyebabkan kebutuhan informasi tunanetra pada tabel di atas dapat digolongkan menjadi dua yaitu kebutuhan informasi tentang hak mereka sebagai warga negara yang memiliki keterbatasan indra penglihatan dan juga kebutuhan informasi tentang bagaimana menuntut hak mereka secara legal.

\section{Dimensi III- Agents}

Agents dalam model kebutuhan informasi yang dikemukakan oleh Moore dibagi menjadi tiga yaitu a) produsen informasi, yaitu pihak yang memproduksi informasi. b) prosesor yaitu pihak yang mengelola informasi sehingga lebih mudah dimanfaatkan oleh pengguna, c) dan terakhir adalah c) pencari yaitu pihak yang menggunakan informasi.

Berdasarkan hasil penelitian ditemukan bahwa pihak yang berperan sebagai produsen informasi pada pemilihan umum serentak adalah pada komunitas Pertuni adalah Komisi Pemilihan 
Umum (KPU) Kota Malang. Saat mewancarai perwakilan dari KPU Malang, narasumber menyatakan bahwa sebelum pemilihan umum serentak dan pemilihan umum sebelumnya mereka selalu mengadakan sosialisasi melalui FOMI (Forum Malang Inklusi). FOMI merupakan organisasi lintas difabilitas yang bertujuan untuk membangun masyarakat inklusi Malang.

Adapun informasi yang disampaikan berkaitan dengan pentingnya keikutsertaan dalam proses pemilu sebagai wujud sumbangsih warga negara bagi kemajuan Indonesia dan literasi kewarganegaraan. Menurut narasumber dari KPU pemberian informasi tersebut dikemas melalui acara sosialisasi tanpa membedakan jenis difabilitas.

Saat pernyataan dari narasumber KPU ditanyakan ke pihak Komunitas Pertuni Malang, pihak komunitas menyatakan bahwa memang benar ada perwakilan dari tunanetra yang mengikuti sosialisasi tersebut, tetapi karena informasi yang disampaikan pada sosialisasi tidak disebarluaskan oleh perwakilan tunanetra yang mengikuti acara sosialisasi maka pihak komunitas mengajukan permohonan kepada KPU untuk melakukan sosialisasi khusus pada komunitas mereka, permohonan tersebut disetujui oleh KPU, tetapi sampai masa pemilu serentak 2019 selesai sosialisasi khusus tersebut tidak dilaksanakan.

"Saya sudah mengajukan permohonan ke pihak KPU. Pertimbangannya karena kami-kami ini kebutuhan informasinya tidak bisa disamakan dengan difabilitas lain, sosialisasi yang diadakan melalui FOMI itu disamakan mba, jadi kurang mengena untuk tunanetra, setelah disetujui sampai sekarang tidak dilakukan sosialisasi tersebut " (Sunu)

Alasan KPU melakukan sosialisasi hanya melalui FOMI dan tidak memenuhi permintaan khusus dari Komunitas Pertuni disebabkan karena informasi-informasi tentang pemilu sudah di sebarluaskan melalui website KPU, tanggung jawab KPU berhenti pada saat informasi tersebut telah diterbitkan di web, masalah informasi tersebut sampai kepihak komunitas bukan lagi tanggung jawab KPU"

"sekarang kan sudah zamannya teknologi, jadi kami menerbitkan informasi melalui web, masalah informasi tersebut sampai ke tunanetra atau tidak bukan tanggung jawab kami, karena kami tidak bisa memastikan bahwa informasi tersebut sampai untuk semua orang, sampai tidaknya informasi tergantung pada kesadaran individu, mau tidak mencari informasi tentang pemilu. Kalau harus datang ke komunitas satu persatu kami tidak ada biaya, kan sudah kami terbitkan melalui web" (Afi)

Dari kutipan wawancara pihak KPU dan Komunitas Pertuni kita bisa melihat adanya perbedaan pendapat dari produsen informasi dan konsumen. Produsen informasi beranggapan bahwa tanggung jawab mereka selesai pada saat menerbitkan informasi tentang pemilu, sementara pihak konsumen beranggapan bahwa produsen seharusnya mempunyai tanggung jawab untuk menerbitkan informasi yang sesuai dengan kebutuhan mereka dan harus menyampaikan informasi tersebut ketangan mereka agar bisa dimanfaatkan dalam Pemilu Serentak 2019.

Komunitas Pertuni Malang sebagai pencari informasi menunjukkan perilaku aktif dalam pencarian kebutuhan informasi mereka. Pihak komunitas menyadari bahwa informasi yang didapatkan melalui kegiatan sosialisasi dari KPU belum bisa memenuhi kebutuhan informasi mereka, sehingga mereka berusaha untuk memenuhi kebutuhan informasi dengan mengajukan permohonan agar KPU bersedia melakukan sosialisasi khusus sesuai dengan kebutuhan mereka, selain mengajukan permintaan ke KPU, Pertuni juga berusaha memenuhi kebutuhan informasinya dengan cara menghubungi Komunitas Pertuni lain yang ada di luar Malang, sehingga mereka bisa menggunakan beberapa informasi yang relevan dengan kebutuhan informasi untuk diterapkan dalam pemilihan umum serentak 2019.

Keaktifan komunitas pertuni malang sebagai konsumen informasi dimana mereka memiliki kesadaran akan kekurangan yang dimiliki dan berusaha secara aktif untuk memenuhi kekurangan tersebut merupakan suatu indikator penting yang menunjukan kemampuan komunitas dalam 
meningkatkan kualitas hidup anggotanya. Pernyataan ini didukung kuat oleh pendapat Paulo Freire yang menyatakan bahwa kelompok masyarakat minoritas hanya bisa dibebaskan dari tekanan dan ketidakadilan jika mereka memiliki kesadaran kritis tentang kondisi mereka, mampu mengidentifikasi kebutuhan sebagai modal untuk berkembang dan berupaya untuk memenuhi kebutuhan tersebut demi memberdayakan anggotanya (Freire dalam Nwafor dan Chigbu, 2017).

Pada kenyataannya, pernyataan dari Freire tersebut sulit untuk diaplikasikan dalam kehidupan nyata. Komunitas Pertuni yang sudah berusaha untuk aktif tetapi ternyata tetap tidak mampu memenuhi kebutuhan informasinya. Kekritisan dan keaktifan kelompok masyarakat minoritas dalam memenuhi kebutuhan kelompoknya tidak serta merta mampu memberdayakan anggotanya, karena kelompok minoritas tersebut membutuhkan bantuan dari kelompok masyarakat lain untuk memenuhi kebutuhannya.

Pada konteks Komunitas Pertuni dalam usahanya memenuhi kebutuhan informasi tentang Pemilu Serentak 2019, komunitas memerlukan bantuan dari kelompok masyarakat lain untuk berperan sebagai prosesor.

Prosesor pada nantinya berperan dalam mengemas ulang informasi yang diberikan oleh produsen agar bisa digunakan oleh komunitas pertuni dengan maksimal, sehingga setelah KPU menerbitkan informasi yang berkaitan dengan pemilu, pihak prosesor bisa mengelola informasi tersebut dengan berbagai cara misal dengan menggabungkan informasi yang diterbitkan KPU dengan informasi lain sehingga lebih relevan, bisa mengubah informasi teks menjadi audio, dsb. Pihak yang mempunyai potensi untuk dijadikan prosesor adalah Pengurus Pertuni Malang dan Malang Corruption Watch (MCW).

Pengurus Pertuni Malang mempunyai potensi strategis untuk dijadikan prosesor karena pengetahuan dan peran pengurus dalam komunitas. Berdasarkan hasil observasi ditemukan bahwa pengurus menunjukkan perilaku informasi yang lebih aktif daripada anggota komunitas, sehingga tidak mengherankan bahwa mereka memiliki pengetahuan dan ketrampilan untuk mengelola informasi menjadi informasi yang relevan untuk kebutuhan tunanetra sehingga dengan memposisikan pengurus menjadi prosesor untuk komunitas merupakan langkah yang strategis.

Kemampuan yang dimiliki oleh pengurus sebagai prosesor tidak akan bisa maksimal apabila mereka tidak bekerjasama dengan pihak di luar komunitas. Hal ini terjadi karena pengurus memiliki pengetahuan mendalam tentang komunitas tunanetra tetapi informasi tentang apa yang terjadi di luar komunitas terbatas sehingga mereka perlu menjalin kerjasama dengan pihak luar yaitu Malang Corruption Watch (MCW), yang juga berpotensi untuk dijadikan prosesor karena tujuan dibentuknya MCW adalah untuk meningkatkan pemberdayaan masyarakat minoritas salah satunya melalui informasi. Menurut pernyataan narasumber dari MCW mereka selama ini sudah memndampingi Komunitas Pertuni Malang dalam melakukan advokasi dengan menyediakan informasi-informasi yang relevan dengan isu yang dihadapi oleh Pertuni dan juga memberikan pendampingan dalam mengaplikasikan informasi tersebut untuk menyelesaikan permasalahan (Intan, 2019).

Kesimpulan dari dimensi agents adalah KPU yang berperan sebagai produsen informasi tentang pemilihan umum serentak 2019 memiliki pemahaman berbeda dari pencari informasi yaitu komunitas pertuni malang. Perbedaan pemahaman ini menyebabkan komunitas pertuni belum bisa memenuhi kebutuhan informasi akan pemilihan umum serentak 2019 dengan maksimal, untuk menyelesaikan permasalahan tersebut maka pertuni dan KPU membutuhkan prosesor informasi, pihak yang mempunyai potensi untuk memenuhi peran tersebut adalah pengurus Komunitas Pertuni Malang dan MCW. 


\section{Dimensi IV-Mechanisms}

Dimensi mechanisms pada model yang dikemukakan oleh Moore merepresentasikan cara yang dilakukan untuk memenuhi kebutuhan informasi, yang terdiri dari komunikasi, media masa, internet, dan perpustakaan, (Moore, 2002). Berdasarkan observasi dan wawancara yang dilakukan ditemukan bahwa mekanisme yang dilakukan oleh Komunitas Pertuni Malang dalam memenuhi kebutuhan informasi tentang Pemilu Serentak 2019 dilakukan melalui dua cara yaitu komunikasi dengan anggota pertuni dan mengakses media masa yaitu televisi. Berikut ini kutipan wawancara dari anggota Komunitas Pertuni Malang:

"untuk informasi tentang pemilu ya nonton televisi, tapi yang saya pilih hanya berita dari TV One saja, karena beritanya bagus tidak seperti berita yang lain” (Bambang)

"lebih banyak dari berita di televisi mba, terus ngobrol dengan teman-teman di pertuni juga karena kita kan setiap bulan ada arisan anggota, terus beberapa kali itu ada caleg yang datang ke kita , jadi ya dari situ aja" (Aci)

"di televisi dan dari teman-teman pertuni, saya juga sering menghubungi teman-teman pertuni di daerah lain, untuk ngecek di pemilu ini mereka dapat informasi apa saja, jangan-jangan hanya Pertuni Malang yang ketinggalan atau Cuma kita yang tahu tentang berita itu, ya sharing lah intinya" (Sunu)

Kecenderungan anggota komunitas memenuhi kebutuhan informasi tentang pemilu melalui televisi dan melalui komunikasi dengan anggota Pertuni Malang ataupun anggota pertuni di daerah lain menurut Moore terjadi karena dua faktor yaitu environmental scanning dan tailored information (Moore, 2002). Informasi tentang Pemilihan Umum Serentak 2019 berkaitan dengan isu-isu di luar komunitas yang memiliki skala nasional dan bahkan internasional, sehingga untuk dapat memenuhi kebutuhan informasi tentang Pemilihan Umum Serentak tahun 2019, pihak Pertuni harus melakukan scanning informasi terkait pemilu dari lingkungan di sekitar mereka.

Televisi dipilih sebagai media untuk melakukan environmental scanning karena sifat informasi yang ada di televisi yang sangat beragam tentang isu-isu terbaru yang ada di masyarakat dan informasi tersebut bisa diakses oleh tunanetra di pertuni melalui audio, selain itu harga telivisi yang terjangkau menyebabkan televisi menjadi tool yang strategis untuk melakukan environmental scanning informasi tentang pemilu.

Informasi yang didapatkan dari environmental scanning melalui televisi masih bersifat umum seperti informasi tentang jadwal pelaksanaan pemilu, informasi tentang calon presiden dan wakil presiden, dan juga isu-isu tentang persiapan pelaksanaan pemilu serentak, agar informasi tersebut bisa dimanfaatkan dengan lebih maksimal selanjutnya anggota melakukan komunikasi (diskusi) dengan pengurus. Dalam diskusi tersebut terjadi proses personalisasi informasi.

Personalisasi informasi disini maksudnya adalah pihak pengurus komunitas pertuni menggabungkan informasi bersifat umum yang didapatkan dengan kebutuhan informasi komunitas sehingga pada saat kegiatan diskusi mereka mampu memberikan informasi yang lebih relevan daripada informasi yang didapatkan melalui televisi. Informasi-informasi tersebut contohnya adalah informasi tentang tidak tersedianya surat suara huruf braille dalam kegiatan pemilu serentak, rencana sosialisasi untuk pemilu, bahkan informasi tentang calon legislatif mana yang lebih peduli dengan nasib komunitas tunanetra pun bisa didapatkan dari diskusi bersama.

Anggota komunitas menyatakan bahwa saat memerlukan informasi tentang pemilihan umum yang berkaitan dengan tunanetra anggota lebih memilih untuk memenuhi kebutuhan tersebut melalui komunikasi dengan pengurus komunitas mereka menganggap bahwa informasi yang didapatkan dari pengurus lebih spesifik dan terpercaya. Berikut ini adalah kutipan wawancaranya:

"lebih memilih tanya ke Pak Tri mba, karena beliau mendapatkan informasi dari mana-mana, dan tidak mungkin informasi yang diberikan beliau itu merugikan, kan beliau ketua jadi lebih bertanggung jawab" (Aci) 
Pernyataan dari anggota komunitas sesuai dengan pendapat dari Wilson yang menyatakan bahwa peran seseorang dalam lingkungan sosial berpengaruh terhadap perilaku informasi orang tersebut. Saat seseorang mempunyai peran signifikan dalam lingkungan sosial peran tersebut akan mendorong individu untuk lebih aktif dalam mencari informasi dan lebih berhati-hati dalam menjaga kebenaran informasi yang disebarkannya (Wilson dalam Kundu, 2017), sehingga tidak mengherankan jika anggota komunitas mempercayai pemenuhan kebutuhan informasi tentang pemilu kepada pihak pengurus komunitas.

Kepercayaan anggota komunitas dalam memilih mekanisme berupa komunikasi dengan pengurus komunitas juga didasari adanya faktor sense of community yang kuat dalam komunitas tersebut. Sense of community adalah suatu kondisi psikologis dalam sebuah komunitas dimana mereka merasa menjadi suatu kesatuan, berbagi emosi yang sama, pengalaman , dan nilai-nilai yang sama (McMillan, 1986). Sense of community tersebut membangun rasa kepercayaan yang tinggi antar anggota komunitas, mereka percaya bahwa pengurus tidak akan memberikan informasi yang menyebabkan mereka terdisorientasi secara politik, anggota bahkan lebih percaya kepada informasi yang telah di personalisasi oleh pengurus daripada informasi dari televisi atau dari unsur apapun di luar komunitas mereka.

Kesimpulan pada dimensi mekanisme adalah komunitas pertuni dalam memenuhi kebutuhan informasi tentang Pemilu Serentak 2019 memilih mengkombinasikan informasi yang mereka dapatkan dari televisi dan berkomunikasi dengan pengurus komunitas. Informasi didapatkan melalui proses environmental scanning dan juga personalisasi, dimana anggota komunitas mencari informasi tentang pemilu dari lingkungan sekitar yang kemudian mereka sesuaikan dengan kebutuhan informasi mereka sebagai tunanetra melalui proses komunikasi dengan pengurus komunitas.

\section{SIMPULAN}

Kebutuhan informasi Komunitas Pertuni Malang dianalisis menggunakan model kebutuhan informasi sosial dari Moore, dilihat dari tiga dimensi yaitu function, form, agents dan mechanisms menunjukkan bahwa informasi yang di dapatkan pada masa pemilu serentak belum secara maksimal memenuhi kebutuhan mereka.

Belum terpenuhinya kebutuhan mereka secara maksimal disebabkan karena dua faktor yaitu dari segi konten dan media penyebaran informasi. Dari segi konten informasi yang diberikan kepada tunanetra selama pemilu serentak 2019 tidak dirancang untuk memfasilitasi kebutuhan khusus mereka sebagai tunanetra. Adapun informasi tentang tata cara pemilihan, template braille, advokasi apabila hak mereka tidak diperoleh dalam pemilu, dan juga latar belakang calon legislatif.

Kedua berkaitan dengan media penyebaran informasi dimana KPU Malang memilih melakukan penyebaran informasi melalui FOMI ataupun website KPU, dimana pihak komunitas tidak melakukan pencarian informasi melalui kedua media tersebut.

Dari dua faktor di atas maka upaya yang perlu dilakukan pihak-pihak terkait untuk pemilihan umum pada periode yang akan datang adalah saat memberikan informasi harus terlebih dahulu menganalisis kebutuhan informasi komunitas DPC Pertuni Malang, jangan dilakukan searah dimana pihak produsen informasi memberikan informasi yang menurut mereka dibutuhkan oleh komunitas DPC Pertuni Malang . Kedua lakukan pendampingan selama proses pengaksesan dan pemanfaatan informasi, dan yang terakhir adalah melakukan evaluasi dengan melibatkan pihak komunitas. 


\section{DAFTAR PUSTAKA}

Alexander, R.. (2009). Political Literacy as Information Literacy. Georgia International Conference on Information Literacy. 28.

Andriadi, F., \& Rosdi, A. (2016). Demokrasi di tangan netizen. Jakarta: RMBooks.

Braman, S. (2007). Change of state: information, policy, and power. Cambridge, MA: MIT Press.

Heryanto, G. G. (2019). Literasi politik: dinamika konsolidasi demokrasi Indonesia pascareformasi. Yogyakarta: IRCiSoD.

Intan. (2019). Wawancara Personal, "Literasi Informasi Bidang Politik Komunitas DPC Malang”. Juni 2019.

Kamran, A. (2015). Negotiating the Digital Maze of Information Literacy: A Review of Literature. Diunduh dari https://www.academia.edu/36270057/Negotiating_the_Digital_Maze_of_Information_Liter acy_A_Review_of_Literature.

Kementrian Komunikasi dan Informatika. (2019). Buku Pintar Pemilu 2019. Diunduh dari https://agamkab.go.id/template/file/upload/fileupload_1553225220.pdf.

Kundu, D.K. (2017). Models of Information Seeking Behaviour: A Comparative Study. International Journal of Library and Information Studies, 7(4). http://ijlis.org/img/2017_Vol_7_Issue_4/393-405.pdf

Lestari, R. D. (2017). Kebutuhan Informasi Penyandang Cacat Tunanetra SMPLB YPAB Surabaya. Diunduh dari http://repository.unair.ac.id/15520/.

Liputan 6. (2014). Tak Ada Braile di Surat Suara, Penyandang Tuna Netra Demo. Diunduh dari https://www.liputan6.com/news/read/2028613/tak-ada-braile-di-surat-suara-penyandangtuna-netra-demo

Mc. Millan.,\& M.Chavis. (1986). Sense of Community: A Definition and Theory. Journal Of Community Psychology, 14

Moore, N. (2002). A model of social information need. Journal of Information Science, 28(4), 297 303. doi: 10.1177/016555150202800404

Nwafor \& Chigbu. (2017). Information Literacy Skills Required by Blind and visually Impaired Students for Effective Information Access in the University of Nigeria, Nsukka. Library Philosophy and Practice. 15. 10.31641/ulj150205.

Republik Indonesia. (1999). Undang-Undang Nomor 39 Tahun 1999 tentang Hak Asasi Manusia

Suryadi. (2019). Wawancara Personal, "Literasi Informasi Bidang Politik Komunitas DPC Malang”. Juni 2019.

UNDP. (2017)Leave no one behind,' UNDP aims to champion the rights of visually impaired people in Indonesia. UNDP in Indonesia. Retrieved November 19, 2019, from 
https://www.id.undp.org/content/indonesia/en/home/presscenter/articles/2017/08/31/_leaveno-one-behind--undp-aims-to-champion-the-rights-of-visual.html

Willson, T.D. (2016). A General Theory Of Human Information Behaviour. Proceedings of ISIC: the information behaviour conference, Zadar, Croatia, 20-23 September, 2016: Part 1

Wurman, R. S. (2000). Information anxiety. Indianapolis, IN: Que. 